\title{
Multinational Staff Effectiveness in UN Peace Operations: The Case of the U.S. Army and UNMIH, 1994-1995
}

\author{
WALTERE. KRETCHIK
}

ince the end of the Cold War, U.S. Army personnel have participated $\omega$ in United Nations peace operations (e.g., Somalia, Rwanda, and Haiti) as part of a multinational headquarters. Diverse by nature, UN military staffs do not share the common procedures that assist in military organizational effectiveness at the operational and tactical level of military operations. ${ }^{1}$ By the mid-1990s, U.S. Army senior officers perceived that UN multinational headquarters were ineffective in directing peace operations and that immediate action was necessary to rectify the situation. ${ }^{2}$ Why did U.S. Army senior leaders decide to try to improve UN military organizational effectiveness? What steps were taken? What were the results? What does this suggest for future U.S.-UN military peace operations? This article addresses these questions.

This study draws upon the efforts of Allan R. Millett, Williamson Murray, and Kenneth H. Watman. ${ }^{3}$ In 1986, those scholars challenged perceptions that military organizational effectiveness was important only at the tactical level of war, where forces collide in battle. Arguing that organizational effectiveness means more than tactical success, the authors examined a broader range of wartime activities at the political, strategic, operational, and tactical levels. Their work led them to conclude, "one cannot limit the judging of military effectiveness only to non-dynamic assessments of tactical units." 4

WALTER E. KRETCHIK is an assistant professor of history at Bilkent University, Ankara, Turkey. He holds a Ph.D. in history from the University of Kansas. His current research includes U.S. military interventions, U.S. military doctrine, and military operations other than war. Address for correspondence: FEASS Department of History, Bilkent University, 06533 Bilkent, Ankara, Turkey. E-mail: kretchik@bilkent.edu.tr

Armed Forces \& Society, Vol. 29, No. 3, Spring 2003, pp. 393-413. 
Given Millett, Murray, and Watman's analysis, this article argues that military organizational effectiveness is fully as important in military operations other than war as it is during wartime. In addition to war, many armed forces perform a wide range of peacetime missions including peacekeeping, humanitarian assistance, and disaster relief operations. In war or peace, organizational effectiveness seems vital for mission accomplishment.

To gain some appreciation for military organizational effectiveness during military operations other than war, this essay investigates U.S. Army efforts between 1994-1995 to improve the United Nations Mission in Haiti (UNMIH) by developing and implementing a multinational staff training program. This is a preliminary or pilot inquiry only, for it seeks to examine the process that was undertaken and what can be inferred from such a study. ${ }^{5}$ Narrow inquires such as this one favor the historical case study approach, in which the use of records, documents, and interviews allows for an in-depth analysis. ${ }^{6}$ The UNMIH case incorporates UN and U.S. government records and draws from author interviews with key personnel. Moreover, case studies can be either quantitative or qualitative. As a qualitative study, the discussion uses such a descriptive approach to tell the story of why, how, and what may be suggested from an examination of the U.S. Army's commitment to improve UNMIH staff effectiveness over the winter of 1994-1995.

\section{Creating UNMIH}

On 19 September 1994, the day U.S. forces landed in Haiti, the UN published official guidelines for nations contributing military forces to UNMIH. Brigadier General Abdul Ghani Bin Yunus and his assistant, Lieutenant Colonel Willy Vanstraelen, had worked feverishly for several months to develop a guidebook for the UN force. ${ }^{7}$ The eightyfour-page document included the rationale behind UNMIH's formation and pre-deployment personnel training requirements, and sketched out a skeletal UNMIH headquarters organization framework. The projected UNMIH headquarters drew upon 181 members of the UN-mandated 6,000-man peacekeeping force. ${ }^{8}$

While the UNMIH guidelines were an impressive piece of staff work, the booklet contained numerous shortcomings. Because the UN was a non-warfighting organization, the guide lacked the essentials for enumerating exactly what experience a soldier should possess upon assignment to UNMIH and precisely what standards were to be met in certifying an individual as ready for deployment. The lack of specificity 
concerning pre-deployment preparations was typical of UN operations at the time, for it was assumed that each nation's political and military leaders automatically furnished soldiers possessing the appropriate staff skills. In truth, such thinking was more idealistic than realistic. While many national leaders indeed certified their soldiers as meeting mission requirements, some contributing countries, according to U.S. Army observers, failed to provide even one soldier with the proper experience. ${ }^{9}$

Yet a series of events soon unfolded, ensuring that the UNMIH headquarters was more a U.S. contrivance than a UN entity. In a series of messages, Vanstraelen notified various U.S. military liaison officers of the U.S. commitment to provide certain troops to UNMIH. Within a few hours, the U.S. Atlantic Command in Norfolk, Virginia, became responsible for finding suitable personnel from the various U.S. armed forces for the upcoming UN mission. ${ }^{10}$

\section{The U.S. Army Gets Involved}

Sometime on the morning of 21 September 1994, U.S. Army Chief of Staff General Gordon R. Sullivan first became aware of U.S. Atlantic Command's task to supply service personnel to UNMIH. Sullivan, whose duties included providing Army forces to U.S.-sanctioned multinational operations, immediately zeroed in upon the personnel requirements for the UNMIH headquarters staff. During the briefing, Sullivan recalled a 1994 U.S. Army after-action report that lambasted the UN personnel in Mogadishu for their want of fundamental staff procedures and organizational effectiveness. The report implied that the UN headquarters lacked suitable military staff skills to the point at which the headquarters was unable to sort through mission upheaval under pressure." Recalling the catastrophe of 3 October 1993 in Mogadishu, Sullivan was determined to avoid repeating its failures in Port-au-Prince. Within minutes, he had convinced himself that the UNMIH staff personnel required extensive training in U.S. staff procedures to avoid repeating the deadly events of October 1993. ${ }^{12}$

Sullivan soon directed his Deputy Chief of Staff for Operations and Plans, Lieutenant General Paul E. Blackwell, to examine the possibility of using U.S. Army assets to train the UNMIH staff members prior to assuming their duties in Haiti. Blackwell liked the idea and informed Sullivan that an Army staff officer just happened to be traveling to New York the next day to brief the UN Peace Operations Training Division on the U.S. Army lessons from Somalia. Both Sullivan and Blackwell 
agreed that the UN briefing was an opportunity to propose "assisting UN and Joint Staff planning by offering alternatives to speed training of the UNMIH staff."13

As the U.S. Army's senior operations officer, Blackwell had a plethora of training resources to draw upon. Given the proper permissions, Blackwell envisioned assigning the Battle Command Training Program (BCTP), a mobile training team located at Fort Leavenworth, Kansas, and peacekeeping experts from the Joint Readiness Training Center at Fort Polk, Louisiana, to perform the mission. ${ }^{14}$ To lay the groundwork, Blackwell sent a note to Lieutenant General Wesley K. Clark, the JCS Director of Strategic Plans and Policy (J5), to investigate the possibility of training the UNMIH staff. In his letter, he appraised Clark of Sullivan's interest in training the UNMIH headquarters personnel either in the U.S. or in a coalition nation, such as Canada. ${ }^{15}$

Clark's response was immediate and approving. Having secured his endorsement, Sullivan corresponded with JCS Chairman General John M. Shalikashvili to voice his concern over the past weaknesses shown by various UN headquarters in the field. Sullivan warned: "Based upon the lessons learned in Somalia and elsewhere, we can ill afford an ad hoc, unprepared UN staff in Haiti." 16 He suggested that Shalikashvili give some credence to an Army-sponsored training plan designed to professionalize the UNMIH staff personnel. Furthermore, Sullivan urged the chairman to sign a letter addressed to UN Ambassador Madeleine Albright that reminded her of Presidential Decision Directive (PDD) 25 and its requirement to establish a Peace Operations Training Program under the U.S. military. ${ }^{17}$ If the proposal was approved, he also assured the chairman that the U.S. Army was ready to train the UNMIH staff. ${ }^{18}$

Sullivan's plan to "professionalize" UNMIH was in fact a scheme to impose U.S. training standards upon a multinational audience to prevent further UN disasters. As numerous U.S. general officers considered Sullivan's initiative to "Americanize" UNMIH, Colonel Lynn Moore from $\mathrm{BCTP}$ received notice of what was transpiring in Washington. On 28 September 1994, Moore chaired a meeting of key U.S. military training officers at Fort Leavenworth, Kansas, to discuss Sullivan's idea. ${ }^{19}$ After some opening remarks, Moore turned the discussion over to Colonel Steven Wood from the U.S. Atlantic Command. While there was no official word that the U.S. would train the UNMIH staff, Wood was confident that such a mission would be forthcoming, given the level of interest within the Pentagon. When queried by some officers as to why the UN would consent to U.S. staff training methods, he responded that the U.S. Army had offered "to assist but not direct" the UN in 
training the UNMIH headquarters. He thus argued that the UN would approve the Army's training proposal "if packaged correctly" in the interest of organizational cohesion. ${ }^{20}$

Many U.S. officers in attendance had previous experience with the UN and alleged that the multinational staffs were novices in staff management skills when compared to the U.S., British, and French militaries. ${ }^{21}$ Lieutenant Colonel Thomas K. Adams, a peace operations faculty member with the U.S. Army Command and General Staff College, had just returned from Rwanda, "where UN headquarters policy was one thing and reality was another." Adams believed that Sullivan's idea was innovative, for, as he put it: "What we're really trying to do is to take a disparate group of people, military and civilian, of various nationalities and various ranks, experience and background, and create a functional organization, a true UN headquarters, something that has never been done before." 22 In truth, the UN had never trained a multinational headquarters and was unprepared to do so, for "there was no doctrine or model available to train the UNMIH headquarters and it would require detailed planning and outside help to pull it off." 23

Adams' assertion was on target. To prepare the UNMIH staff, the officers required training assistance in at least twenty-two staff areas to include Haitian history, UN functions, coalition building, command and control of military operations, force protection concerns, media and public affairs procedures, and logistics. More importantly, the UNMIH personnel required a common mental framework for problem solving, a clear weakness from past UN operations, so Wood proposed training the staff in the U.S. Army's military decision-making process. He further suggested that BCTP publish a staff officer guidebook, a text that explained the reporting procedures for daily headquarters operations. ${ }^{24}$ The entire training process was estimated to take about ten days. ${ }^{25}$

While Sullivan had envisioned a program to produce multinational staff officers qualified in American thought processes, both Adams and Lieutenant Colonel Dan Ward from BCTP saw things differently. Both officers expressed their concern over the righteousness of the undertaking, challenging the motives behind the training mission, arguing that the UN was not the U.S. military, and that the U.S. Army had no right "to create an American-style staff transposed upon the international community." For Adams, it was "a critical mistake," and he recommended that the training not be an "Americanization" process but a team-building exercise. Once the UNMIH staff attained cohesion, the 
officers would then be capable of the intricate staff work needed to assist the commander. The meeting ended on that note. ${ }^{26}$

\section{Charting a Course}

Back in Washington, the Army staff was working hard to bring Sullivan's vision to fruition. Lieutenant General Blackwell advised U.S. Navy Admiral Paul D. Miller, the Commander-in-Chief (CINC), U.S. Atlantic Command, of Sullivan's plan to train UNMIH. As the U.S. CINC responsible for joint operations within the Caribbean, Miller's headquarters was assigned the task of using U.S. Army and other government assets to assist foreign military forces. ${ }^{27}$ Miller told Blackwell that he had met with the U.S. Army representatives at his headquarters, understood the concept, and that he had accepted Sullivan's offer upon Shalikashvili's confirmation. ${ }^{28}$

By 1 October 1994, and still without UN approval to act, the Army staff provided Colonel Moore from BCTP with guidance for developing the UNMIH training plan in some detail. Moore appointed Lieutenant Colonel Rex Wamsley, an experienced training officer, to develop the concept. Wamsley's concept included the establishment of training syndicates containing a range of experts from agencies within and outside of the U.S. government who understood how to create organizational cohesion. In effect, he had adopted Adams's ideas by stressing the team-building aspects of the mission right from the beginning. ${ }^{29}$

$\mathrm{He}$ also understood that selling an American training strategy required certain other courses in addition to decision-making. The concept thus called for an initial strategic overview detailing why the UN was involved in Haitian affairs, followed by a series of lectures concerning UN peace operations procedures in general. Once the initial briefings ended, the UNMIH staff then participated in team-building exercises to "demonstrate that the staff could function effectively despite the problems of language and varying cultures." Training encompassed the seven UNMIH staff sections plus the special staff responsibilities of law, police work, and public affairs and information. ${ }^{30}$

Under Wamsley's model, the training syndicate members were to design lesson plans that included measurable standards to gauge the staff's progress. Additionally, he wanted to certify the trainers in their areas of instruction before allowing them to teach the UNMIH staff to ensure that they were truly knowledgeable. To do so, he asked Wood to marshal the instructors at Fort Leavenworth, Kansas, in November 1994 , for a training session before deploying to the training site. ${ }^{31}$ 
On 4 October 1994, the UNMIH advanced team for transition between the multinational force and the UN departed for Haiti. At Fort Leavenworth, Colonel Moore approved Wamsley's training plan and forwarded it to U.S. Atlantic Command. Wood and Wamsley were now in daily contact, coordinating details as the JCS received U.S. government approval for Sullivan's concept and the UN Security Council debated its merits. ${ }^{32}$

As the services awaited UN approval for Sullivan's concept, the UNMIH advanced party personnel in Port-au-Prince informed the UN Department of Peacekeeping Operations that it would take about twenty-five days to train the staff to prepare for the upcoming mission. The UNMIH team members believed that once training ended, the staff required two additional weeks to gradually transfer the ongoing military operation from U.S. to UN control. ${ }^{33}$ Thus, once Transition Day was established, it would take about forty days for UNMIH to assume the Haiti operation. ${ }^{34}$

By mid-November, the JCS received indicators that the UN members had viewed the U.S. Army's proposal in a favorable light, but that the training location remained an issue. Lieutenant Colonel Wamsley spent many hours searching for appropriate training facilities in discussion with representatives from the UN, the JCS, and the U.S. Atlantic Command. Fort Leavenworth, Puerto Rico, and Haiti were considered as potential locales, each subject to various financial considerations for site preparation. For example, BCTP personnel estimated that it would cost about $\$ 486,000$ to train the staff in Haiti and over $\$ 500,000$ in Puerto Rico, due to the requirements of shipping equipment, transporting personnel, and installing communications hardware already in place at Fort Leavenworth. Wamsley assured the training officers at the U.S. Atlantic Command that regardless of where the mission occurred, the money was well spent if it saved but one human life. ${ }^{35}$

While training officers at various locations continued to plan, the UN passed SCR 964 on 29 November 1994, authorizing the SecretaryGeneral to progressively strengthen the UNMIH advanced team and to identify the specific conditions required to move operations from the U.S.-controlled multinational force. Two days later, the U.S. Atlantic Command announced that the U.S. 25th Infantry Division from Schofield Barracks, Hawaii, was scheduled to replace the U.S. 10th Mountain Division, Fort Drum, New York, in January 1995, "to set the conditions for a successful transition to UNMIH about March of 1995."36

Soon after the release of SCR 964, Colonel Wood met with members of the UN Peacekeeping Division to go over the training concept for the 
UNMIH staff. Wood reiterated that the U.S. Army's training plan was in support of the UN to ensure that UNMIH was "a unified staff capable of planning and conducting UN peace operations in Haiti." He then described the training as occurring in five phases. Phase One lasted one day and introduced the training faculty and the UNMIH staff members to each other. Mission briefings soon followed, encompassing Haitian history, geography, culture and customs, and a current situation update. The second phase began with a strategic orientation that examined topics including democratic processes, humanitarian concerns, statecraft, and Haitian governmental functions. Phase Three involved two days of individual and group training in military decision-making processes and problem-solving techniques. Once the trainers certified that the UN staff was familiar with decision-making procedures, the students entered Phase Four, or staff building. During Phase Four, the entire staff was scheduled to undergo three days of preparation in UN staff functions, the roles of nongovernmental and private volunteer organizations, coalition building, command relationships, legal issues, nonlethal techniques for handling disturbances, and reporting procedures. Once they completed that phase, the staff engaged in a three-day computer simulation exercise using VICTOR, a peace operation computerized wargame simulation replicating potential situations requiring staff action. During the computer simulation exercise, the staff worked in twenty-four hour shifts to generate reports, coordinate actions, and react to computer-simulated events such as shootings, riots, disease epidemics, and political policy dilemmas. The UNMIH commander was scheduled to participate by receiving daily staff updates and issuing guidance. Trained observers advised the staff and repeated tasks when necessary. After training ended, the staff conducted an after-action review, a facilitated meeting where the group discussed their strengths and weaknesses while learning from successes and failures. Colonel Wood believed that the training scheme was "the most rigorous staff training event that could be devised" and that "it is the right thing to do." 37

\section{Preparing to Act}

On 14 December 1994, Wood notified Wamsley that the UN Security Council had approved the U.S. Army's training proposal and that the UNMIH staff was to be trained in Haiti by mid-March 1995. Wamsley's request to have the trainers undergo a pretraining seminar at Fort Leavenworth, Kansas, was also approved. ${ }^{38}$ 
Over the next week, Wamsley searched for a Haitian cultural expert who had worked previously with the military. Lieutenant Colonel Adams knew of one such individual, Dr. Bryant C. Freeman from the University of Kansas, and asked him if he would serve on the UNMIH training team. Freeman, a fluent French and Haitian Creole speaker, had interviewed Haitian refugees in Guantanamo Bay, Cuba, as a contractor for the Immigration and Naturalization Service. Freeman offered his expertise during the two-week training period for a tidy sum that the U.S. Atlantic Command grudgingly approved. ${ }^{39}$

On 18 December 1994, with the consent of both the UN Department of Peacekeeping Operations and the U.S. Atlantic Command, Wamsley departed Fort Leavenworth with a small party of trainers for a site reconnaissance in Port-au-Prince. There, he met with Canadian Colonel William Fulton, the UNMIH Chief of Staff, to alleviate any concerns about the forthcoming training. Fulton was ecstatic, viewing the American training as essential for creating cohesion among the staff. ${ }^{40}$ Wamsley scrutinized the local facilities for training suitability, figured out airfare requirements, finalized food and lodging issues, and identified the power requirements for computers and telephones. He returned to Kansas and reported that it would cost $\$ 270,000$ to train the UNMIH staff in Haiti. Colonel Wood recommended approval of the funds and forwarded the request for money to the JCS and the UN. ${ }^{41}$

Just after New Years Day 1995, Colonel Tom Moore notified his BCTP training officers that the UN was toying with the idea of training the UNMIH staff from 27 February until 8 March. Wamsley was about to depart for reassignment, so Moore summoned LTC Dan Ward to his office, where he appointed him as the officer-in-charge of UNMIH staff training. Ward described Moore's guidance this way: "It was important to prepare a detailed training concept for both the UNMIH staff in Haiti as well as to train the facilitators at Fort Leavenworth prior to that training. Moore was concerned that the instructors must know exactly what they were doing, what they were teaching, to avoid questions regarding instructor expertise from the UNMIH guys. I assured him that we would not force U.S. ideas and concepts onto the multinational headquarters." 42

The U.S. Army's concern over overt Americanization of the UN operation was formalized in an 11 January 1995 concept paper. The paper stressed the importance of understanding that the multinational personnel were unique and must be approached with a "clean slate" from past UN operations. Within the document, UNMIH was described as "a headquarters of cultural extremes and the training program must 
consider those extremes." ${ }^{43}$ Such extremes included U.S. observations that, while UNMIH required the staff to speak English, language skill levels varied from person to person. In addition, it noted that many senior-level officers from developing countries lacked the basic map reading and driving skills that every U.S. Army lieutenant took for granted. Thus, the concept paper advised that UNMIH staff training should begin with rudimentary skills, then progress to more complex tasks, while not offending the students or violating political taboos. ${ }^{44}$

\section{Readying the Trainers}

In late January 1995, U.S. Ambassador to the UN Madeline Albright met with Major General Maurice Baril and his peacekeeping staff to assure them that the U.S. was capable of executing the UNMIH staff training as soon as practical. On 30 January, Albright received a letter of confirmation from Baril stating: "The UN has provided a response to the US proposal for the UNMIH staff training program. In a letter from UN/DPKO [Department of Peacekeeping Operations] MILAD [Military Advisor] MG Baril, UN, agrees to implement the UNMIH staff training program, requests U.S. to pay for preparation of Haiti training site and for travel and per diem [billeting and food] of US participants, reports that UN will make separate arrangements and pay for travel and per diem of non-US participants, implies that UN will pay for remaining costs under reimbursable basis and promises UN letter of assist[ance] in the near future." 45

Soon after Baril's letter to Albright, the UN Security Council released SCR 975, authorizing the transition of Haitian security responsibility from the U.S. multinational force to UNMIH no later than 31 March 1995. In addition, SCR 975 authorized the Secretary-General to take all necessary steps to ensure that UNMIH was prepared to assume its responsibilities by the specified date and to deploy a total of 6,000 troops to accomplish the mission. ${ }^{46}$

By 6 February 1995, the U.S. Army staff, through the JCS and U.S. Atlantic Command, authorized BCTP to begin the UNMIH training mission. The UN had not approved all the requisite funds, so that UNMIH staff training was reduced from ten to six days. On 27 February 1995, the UNMIH staff trainers arrived at Fort Leavenworth for certification. The group included Brigadier General Abdul Ghani from the UN Department of Peacekeeping Operations, several military officers with peacekeeping experience from Canada, Austria, and the United States, and civilian experts from a variety of UN agencies and academic institutions. ${ }^{47}$ 
Lieutenant Colonel Ward provided an initial overview stressing that, although the UNMIH staff was about to undergo U.S. training methods, the Army remained in support of UN objectives. The trainers then listened to several lectures on how the UN was organized and operated. After the UN orientation, Dr. Bryant Freeman conducted a lecture on Haitian culture, geography, and political concerns, while other lecturers covered other diverse topics. Following the briefings, the trainers participated in a U.S.-designed leadership exercise to demonstrate how seemingly disparate individuals can be assimilated quickly into decision-making groups. ${ }^{48}$

For two additional days, the U.S. Army's BCTP training staff rendered instruction in staff function processes with specific attention given to team building methods. Members of the international community conducted instruction on UN support agency capabilities, followed by a BCTP seminar on the U.S. Army's decision-making methodology. ${ }^{49}$ After the facilitators underwent a series of exercises designed to familiarize them with Army decision-making methods, Colonel Moore certified each trainer as prepared to conduct UNMIH staff instruction.

\section{Americanizing the UNMIH Staff}

The UNMIH training team arrived in Port-au-Prince on 4 March 1995, and training commenced at the Light Industrial Complex (LIC) the next morning. Major General Baril from the UN remarked that forming a cohesive staff capable of implementing SCR 940 and assisting the Haitian government with the establishment of democratic practices was of prime importance. General John Shalikashvili, Chairman, JCS; Major General George Fisher, Commander of Multinational Forces Haiti; and Major General Joseph W. Kinzer, UNMIH commander, each exhorted the UNMIH staff to play a role to assist furthering democratic values in Haiti. In addition, retired Major General Clive Milner spoke about his experiences as a former multinational force commander and the difficulties associated with commanding a large, diverse UN force. ${ }^{50}$

The remainder of the day's events consisted of UN operations and peacekeeping seminars. Representatives from the UN Civilian Affairs Office presented information briefings explaining the UN structure, the command relationship between the UN and UNMIH, and procedures of how different UN agencies supported the UNMIH staff. Lieutenant Colonel Tom Adams then offered a one-hour lecture on the nature of peacekeeping operations, including information on the UN charter, the relationship of political-informational-military aspects of peacekeep- 
ing, the legal authority for the implementation of UNMIH, and civilian population perceptions of UN peacekeepers. ${ }^{51}$

The second session began early on 6 March 1995, with a disputatious Haitian Area Study lecture by Dr. Freeman. Freeman's presence drew objections from two U.S. and Canadian military intelligence officers that included comments that he "was an academic with an agenda." Adams defused the situation, commenting later that "Freeman was very well-received by the UN," and that everyone on the UNMIH staff appreciated Freeman's Haiti experience "except the military intelligence people and to this day I don't understand that." 52 Once the dialogue cooled, Freeman elaborated upon the nuances of Haitian religion, meal schedules and food consumption, personal relationships, gestures, languages, and custom taboos. He further identified how the Haitian people perceived and used power in Haitian society. ${ }^{53}$ Freeman's presentation so impressed Major General Kinzer that the Kansas professor later played a key role in devising UN information leaflets that went out to the local populace. ${ }^{54}$

Following Freeman, the U.S.-led multinational headquarters intelligence section presented a two-hour briefing on the current Haitian social, military, economic, and political situation. UN representatives then stressed the need for Haiti to improve its political and economic conditions due to regional implications for furthering democracy within the Caribbean region. A Norwegian officer with UN peacekeeping experience presented a class on liaison work with host governments and negotiation techniques in which he emphasized the difficulties of trying to mesh UN SCR requirements with host government political and economic desires. Following the lectures, UNMIH staff members organized into functional syndicates such as intelligence, operations, and logistics under the direction of small-group mentors. The mentors trained the staff officers in UN staff processes including routine and emergency reporting procedures and headquarters coordination methods. ${ }^{55}$

The next morning, the functional syndicates formed into mixed groups that included at least one officer from each staff specialty. The students thus created several miniature headquarters, each group containing each of the requisite staff functions that the UNMIH staff had to perform. Each syndicate and its designated mentor spent the day engaged in U.S. Army-designed small group problem solving exercises where the members worked together to resolve difficult tasks such as a scenario where they role-played the survivors of a plane crash in the desert. ${ }^{56}$ Such exercises encouraged individuals to agree on a common 
goal quickly, and then work together as a group to solve the problem. After the exercise, members discussed how they had approached the problem and thus learned from each other. Similar exercises continued until late into the evening of 7 March 1995.

The following day, the staff continued its training with information briefings on UN civil and military policies. Ms. Leila Benkirane from the UN's Office of Legal Affairs spoke on the Status of Mission Agreement, or SOMA, the key legal agreement between the UN and the Government of Haiti that established how peacekeepers enforced the UN resolutions. A member of the U.S. Army Judge Advocate General School then discussed the UN Rules of Engagement (ROE), the guidelines regulating UN troop behavior in accomplishing their tasks. After the ROE briefing, the students participated in a series of U.S.-designed scenarios to test their ROE decision-making abilities.

Numerous trainers then furnished additional information regarding UN mission support in Haiti. BCTP's Major Mark Walsh conducted a seminar on how the UN coordinated activities with outside agencies, international organizations, the government of Haiti, and the use of internal development resources. A representative from the U.S. Agency for Internal Development presented a lecture on the role of newspapers, radios, and television broadcasts in conveying both public and military information to the Haitian people. The final briefings consisted of a series of BCTP-led presentations on U.S. Army decision-making processes using the 1994 edition of U.S. Army Field Manual 101-5 Command and Control For Commanders and Staff. One UNMIH staff officer later recalled that the training "was without a doubt the most intensive staff preparation that he had experienced in his military career." 57

The final training consisted of a BCTP-supervised U.S. computer simulation decision exercise using the VICTOR computer program. The UNMIH staff established a headquarters replicating the one they would occupy on 31 March. For two days, staff officers conducted twenty-four-hour operations with the VICTOR computer generating events such as reports of pilferage, riots, gunfire incidents, and distinguished visitor arrivals. ${ }^{58}$ The staff used their acquired problem-solving skills to respond to the events using U.S.-derived reporting procedures.

In less than forty-eight hours, the UNMIH staff had established a routine and functioned at what the U.S. Army's BCTP trainers deemed "an acceptable level of efficiency" and on 10 March 1995, they completed their training. At a training graduation ceremony, Major General Kinzer announced that the multinational headquarters was 
ready to assume its duties. Proudly, Major General Baril declared that the UNMIH staff had "the appropriate means to assist the Government of Haiti in implementing democratic reform." Several staff officers remarked that they had renewed confidence in themselves and, for the first time, there was a clear understanding of just what was expected of a UN staff. ${ }^{59}$ Twenty-one days later, Kinzer assumed command of UNMIH and his staff commenced their duties.

In 1998 and shortly before his retirement, Lieutenant General Kinzer recalled that the UNMIH staff performed its duties better than any UN organization to date. He attributed the staff's success to the U.S. Army-contrived train-up process that took place in 1995. "The staff was cohesive," he said, "and well-schooled in proper staff procedures." When pressed about why he believed that to be true, the general remarked that UNMIH operated similarly to any U.S. Army headquarters that he was familiar with. ${ }^{60}$ Daily briefings were well organized. Staff officer reports were clear and concise. Daily crises were handled without an inordinate amount of fuss. With confidence in his staff, the commanding general concentrated upon his charter: to assist the government of Haiti in preparing for democratic national elections.

Discussions with UNMIH staff officers divulged similar reports. Colonel Fulton, a veteran of numerous UN deployments, found UNMIH to be more harmonious and efficient than any multinational staff that he had served with. In his opinion, the staff was better prepared to think through complex issues and find plausible solutions because they had a common understanding of the American Army decision-making process. ${ }^{61}$ Other officers held similar views, with many individuals remarking that they understood precisely what they were doing and where they fit within "the big picture."62 For both Kinzer and his staff officers, UNMIH was an organizational effectiveness success story.

\section{Analysis}

This article offered several questions to guide an investigation into organizational effectiveness during UN peace operations. The attempt to answer the question "Why did U.S. Army senior leaders decide to improve UN military organizational effectiveness?" revealed a linkage to 1993 U.S. operations in Somalia. Published after the Mogadishu affair, Presidential Decision Directive 25 provided suggestions for revamping $U N$ peace operations training methods for commanders and other personnel, one indicator that the Somalia experience shaped the U.S. government's views to some degree. ${ }^{63}$ U.S. military after action 
reports from UNISOM II noted serious organizational dysfunction within the UN headquarters in the Somali capital, and correspondence between General Gordon R. Sullivan and General John M. Shalikashvili spoke of avoiding any future ad hoc, unprepared UN headquarters. For U.S. government officials and senior Army officers, staff ineffectiveness in Somalia was a UN specter that required exorcism, in this case through a U.S. Army-driven training program. ${ }^{64}$

In answering "What steps were taken?" it was clear that General Gordon R. Sullivan played a critical role. His position as Army Chief of Staff allowed him to put his vision of an effective UNMIH staff into motion. The task was not simple and required weaving the Army's agenda through a bureaucratic maze. At the political level, the Army leadership worked with the UN and its Department of Peacekeeping Operations, as well as the U.S. government and several military commands, to gain consensus for the training. While U.S. Army methods for decision-making and routine staff work constituted the core instruction, it was multilateral agreement over additional courses such as democracy, the role of peacekeepers, and cultural awareness that made the training palatable in an international venue. To his credit, Sullivan carefully sold his vision as being in support of UN objectives, thus gaining both international approval and achieving his purpose.

While the senior military leadership worked through the politics, a variety of international training officers devised a process suitable for transferring staff skills to the UNMIH staff. American army officers had the lead; they devised a process consisting of five sequential steps: identify the appropriate tasks for training, form the training team, train the trainers, train the target audience, and assess the results. The trainers, however, came from a variety of sources, government and elsewhere, and were very experienced. Their credibility, coupled with intrinsic understanding of their audience, also contributed to mission success.

Organizational effectiveness was built through a simple concept: team building. In addition to mundane instruction in office procedures, officers underwent a series of problem-solving exercises where they learned to work together as a diverse multicultural group. Thus, their courses assisted in breaking down cultural barriers through group work. Each officer not only garnered experience relevant to a particular function but also gained an appreciation for the tasks that every other officer had to perform. Training created a shared experience that allowed UNMIH personnel to understand what was expected of individuals and the group. 
Assessing "What were the results?" is problematic, particularly because it involves qualitative judgements. Yet participant perceptions serve as some indication of measuring organizational efficiency. For Lieutenant General Kinzer, the training process increased his confidence in staff members to carry out their duties efficiently and effectively. The training team was satisfied that their students were certified to handle virtually any situation. The staff members understood their roles and the procedures that they must follow to allow the headquarters to function effectively. During daily operations in Haiti, Kinzer left the headquarters frequently and without hesitation, knowing that his staff was handling any situation as it arose. For their part, the staff members went about their work without ado, managing a myriad of complex tasks and working through the challenges that faced them. From participants' reactions, the training process increased organizational effectiveness.

What does this case study suggest for future U.S.-UN military peace operations? The answers to that question remain unclear, for additional questions now come to the fore. Did the UN institutionalize staff predeployment training for other operations such as Bosnia or Kosovo? Does a carefully planned training process increase organizational effectiveness only in cases where there is adequate time and the resources to prepare a staff, or can this procedure work under constraints? Did UNMIH veterans take the process to their home nations and institutionalize it as a way to improve organizational effectiveness there?

This study sheds little light upon any of these questions, and further research must be undertaken to determine if the UNMIH training process was an interesting anomaly or a model for the future. Regardless, one cannot fully appreciate military organizational effectiveness only by examining war. To assess military effectiveness, one must also scrutinize organizations during military operations other than war. The Haiti case provides one such opportunity.

\section{Notes}

1. Francis Henn, "UN Peacekeeping: The Mirror Should Be Polished." Contemporary Review (June 1994): 281-288. "Level" is a theoretical construct for how U.S. military forces group activities. The operational level is where multiservice and/or multinational forces combine their efforts to devise and execute operations. The tactical level is subordinate to the operational level, where a single service fights battles or executes missions using small units.

2. Department of the Army, Operation Restore Hope After Action Report (Fort Leavenworth, KS: Center For Army Lessons Learned, 1993), secs. III-1 through 
III-9. This particular report addresses UN staff procedures in Somalia. For a personal view, see S. L. Arnold, "Somalia: An Operation Other Than War," Military Review, 9 December 1993): 26-35. Arnold commanded U.S. forces in Somalia.

3. Allan R. Millett, Williamson Murray, and Kenneth H. Watman, "The Effectiveness of Military Organizations." International Security (Summer 1986): 37-71.

4. Ibid., 70-71.

5. See Eileen M. Flanigan and Jon Scott, Process Improvement: How to Change Your Organization's Effectiveness (Menlo Park, CA: Crisp Publications, Inc., 1995).

6. Robert B. Burns, Introduction To Research Methods. (London: SAGE Publications, 2000), 461. Robert Yin, Case Study Research: Design and Methods, 2d ed. (Newbury Park, CA: Sage Publications. 1994).

7. United Nations, Guidelines For Governments Contributing Military Personnel to UNMIH (New York: The United Nations, 19 September 1994). Battle Command Training Program Archives, Fort Leavenworth, Kansas [henceforth called BCTP archives].

8. United Nations, Guidelines, D-1 to D-3. The multinational headquarters staff reflected a typical military organization with a Chief of Staff heading the subordinate staff sections of Military Assistant, Military Personnel and Administration (G1), Operations Branch (G3), and Logistics Branch (G4).

9. Interview with Lieutenant Colonel Kevin C. Benson by author, Fort Leavenworth, Kansas, 20 January 1998. Benson was the Executive Officer for U.S. forces in Haiti during the UNMIH mission and observed UN personnel firsthand. Interview with Lieutenant General Joseph W. Kinzer by author, Fort Sam Houston, Texas, 28 June 1998. As a Major General, Kinzer had commanded UNMIH for one year during 1995-1996.

10. Within the Department of Defense security structure, various U.S. multiservice headquarters have regional responsibilities for crises and contingencies around the world. At the time, the U.S. Atlantic Command was accountable for actions in the Caribbean.

11. Undated BCTP Report, "Proposed Training For UNMIH Staff." BCTP archives.

12. Sullivan was deeply troubled over the loss of American lives in Somalia. Other U.S. government officials also felt the strain, given the subsequent resignation of U.S. Secretary of Defense Les Aspin.

13. Department of the Army, memorandum from General Gordon R. Sullivan to Lieutenant General Paul Blackwell, 21 September 1994, "Subject: UNMIH Staff Training." BCTP archives.

14. The Battle Command Training Program, a grouping of four mobile training teams consisting of military officers who are expert in various areas of military doctrine, is organized into four teams. Team Delta, the organization responsible for training U.S. Army units in multiservice and multinational operations, was thus the logical choice to form the core of subject matter experts for training the UNMIH staff. 
15. Department of the Army, letter from Paul E. Blackwell to Wesley K. Clark, 22 September 1994, subject unspecified. Department of the Army, information paper from Department of the Army Training Management Office to BCTP, 22 September 1994, "Subject: Training of UN force for Peacekeeping Operations in Haiti." BCTP archives.

16. Department of the Army, letter from General Gordon R. Sullivan to General John M. Shalikashvili, 24 September 1994, "Subject: UNMIH Staff Training." BCTP archives.

17. Department of Defense, unpublished briefing slides, "Presidential Decision Directive-56: Managing Complex Contingency Operations," Office of the Assistant Secretary of Defense, Strategic Requirements. The briefing references PDD-25 as the framework for establishing the armed services to examine the factors necessary to use U.S. military forces in peace operations. BCTP archives.

18. Department of the Army, "Sullivan letter to Shalikashvili," enclosure 3. BCTP archives.

19. Author unknown, "Meeting Notes, 28 September 1994." BCTP archives. The notes probably belonged to Ward. Attending the meeting were representatives from various locations, including the JCS, the U.S. Atlantic Command, the U.S. Army War College Peacekeeping Institute at Carlisle Barracks, Pennsylvania, the Department of Joint and Combined Operations, U.S. Army Command and General Staff College at Fort Leavenworth, and BCTP.

20. Interview with Lieutenant Colonel Tom Adams by author, 16 November 1995, Fort Leavenworth, Kansas.

21. United States Atlantic Command, "Untitled USACOM Briefing Slides," UNMIH Staff Training Conference, Norfolk, Virginia, 28 September 1998. BCTP archives. Interview with Lieutenant Colonel George Steuber by author, Fort Leavenworth, Kansas, April 1998. Steuber was the operations officer for U.S. forces in Somalia during UNISOM II and has abundant experience working with UN staffs.

22. Adams interview.

23. Adams interview.

24. Adams interview.

25. Adams interview.

26. Adams interview.

27. The United States National Security Strategy calls for dividing the majority of the world into regions placed under the watchful eye of four-star level military commanders. Called Commanders-in-Chief, CinCs, or Combatant Commanders, the general officers are responsible for monitoring events within their areas of responsibilities and advising the President and the Secretary of Defense concerning the use of military force in times of crisis. See Armed Forces Staff College Publication 1, The Joint Staff Officers Guide, 1998. Norfolk, VA: Armed Forces Staff College, 1998. 
28. Department of the Army, letter from Lieutenant General Paul E. Blackwell to Admiral Paul D. Miller, 29 September 1994, subject unspecified. Note from Admiral Paul D. Miller to Lieutenant General Paul E. Blackwell, undated, subject unspecified. BCTP archives.

29. Battle Command Training Program, Memorandum from Lieutenant Colonel Bill Wamsley to Colonel Moore, undated, "Training Proposal." BCTP archives.

30. BCTP Memorandum, "Training Proposal." The seven staff sections included personnel, information, current operations/plans, logistics, future operations, communications, and civil affairs operations.

31. Department of the Army, BCTP Training Support Briefing Slides, 1 October 1994, untitled. BCTP archives.

32. Headquarters U.S. Atlantic Command, Facsimile Message to BCTP Team Delta, 11 October 1994 "Subject: UNMIH Personnel Roster." BCTP archives.

33. United Nations Mission in Haiti Briefing Slides, 22 October 1994, untitled. BCTP archives.

34. Transition Day was the date established by mutual agreement to begin the process of shifting the mission from the U.S. to the UN.

35. Battle Command Training Program, Operations Group Delta message, 16 November 1994, "Subject: Projected UNMIH Staff Training Cost Estimates." BCTP archives.

36. Headquarters U.S. Atlantic Command, message, 3 December 1994, "Subject: Proposed Public Affairs Press Release Announcing 25th ID Deployment." BCTP archives.

37. Headquarters U.S. Atlantic Command, Training Briefing Slides, 8 December 1994, untitled. BCTP archives. Adams interview.

38. Lieutenant Colonel Gary Hovatter, unpublished memorandum for record, 14 December 1994, "Subject: BCTP Training Support for UNMIH Staff." BCTP archives.

39. Dr. Bryant C. Freeman, unpublished letter to Lieutenant Colonel Tom Adams, 21 December 1994, "Position Proposal." BCTP archives. The $\$ 10,000$ consulting fee was considered a bargain due to Freeman's expertise, as LTC Adams told me in April 1995. Yet several members of the U.S. Atlantic Command staff thought that the fee was exorbitant and believed that it was Freeman's patriotic duty to work for free. Adams retorted that Freeman was indeed a patriot but even a patriot needs to eat.

40. Colonel William Fulton interview by Dr. Robert F. Baumann, Port-au-Prince, Haiti, January 1996.

41. BCTP briefing slides, 19-22 December 1994, "Subject: UNMIH Training Site Survey." BCTP archives.

42. Interview with Lieutenant Colonel Daniel Ward by author, May 1995, Fort Leavenworth, Kansas.

43. Lieutenant Colonel Daniel Ward, unpublished memorandum, 11 January 1995, "Subject: Concept for Training a Multinational Task Force," 1. BCTP archives. 
44. Ward, "Concept for Training," 2.

45. U.S. Mission to the United Nations, electronic message number RUCNDT \#0368 0302335, 30 January, 1995, “Subject: UNMIH Staff Training Program.” BCTP archives.

46. United Nations, UN Security Council Resolution 975, 30 January 1995.

47. Battle Command Training Program, unpublished manuscript, undated, "UNMIH training personnel roster." BCTP archives.

48. Battle Command Training Program, unpublished manuscript, 27 February 1995, "UNMIH Facilitator Training." BCTP archives.

49. Ward interview.

50. Battle Command Training Program, unpublished manuscript, 5 March 1995, "UNMIH Training Schedule." BCTP archives.

51. BCTP, "UNMIH Training Schedule," 7.

52. Adams interview. Dr. Bryant C. Freeman comments to author, October 1996, Montrois, Haiti. The argument revealed much about conflicting cultures between academia and the military. Freeman was a subject matter expert, something that the military intelligence officers fancied themselves as well. Freeman's knowledge was more in-depth, reflective, and based upon experience and study. The intelligence officers had vast, practical experience but only limited time to reflect upon what they knew. The two views, academic and practitioner, obviously clashed in this instance.

53. Adams interview. According to Adams, Freeman talked for two hours and covered Haitian geography, environmental concerns, the political climate and social strata, and Haitian history. He also lectured upon Haitian views of morality, the nation's birth and death rates, the local attitudes regarding foreigners and each natives, economics, and issues concerning everyday life in Haiti.

54. Kinzer interview.

55. Battle Command Training Program, unpublished manuscript, 6 March, 1995, "Revised UNMIH Training Schedule." BCTP archives.

56. BCTP, "Revised UNMIH Training Schedule." Students were told that they could either stay where they crashed and await rescue or attempt to reach a military outpost about a four-day walk away. To assist them in making a decision, they had fourteen pieces of scavenged equipment, such as rations and water for three days, a broken radio and signal mirror, a flare gun, a small tarp, a can opener, and other items, to use as and how they saw fit. Moreover, they not only had to determine how to use the equipment but had only forty minutes to come up with a feasible plan either to stay or move on before a murderous sand storm arrived at their location.

57. Unidentified Canadian lieutenant colonel, BCTP unpublished manuscript, 18 March, 1995, "UNMIH After Action Report." BCTP archives.

58. A typical exercise day began with a thirty-minute shift-change briefing as one half of the staff handed over duties to the oncoming shift. The UNMIH commander then 
received a morning update briefing regarding significant activities in the past twelve hours, a schedule for the current day, and a list of critical events that were expected within the next few weeks. Adams interview.

59. Fulton interview.

60. Kinzer interview.

61. Fulton interview.

62. Steuber interview. Ward interview. Ward related comments received by various multinational officers, including written feedback concerning their training and the assessment of their duties during the operation.

63. PDD-25 was released 22 February 1996 and included eleven steps to strengthen UN management of peace operations and to direct U.S. support for strengthening the UN's planning, logistics, information and command and control capabilities. See "Presidential Decision Directive 25" [report online], accessed 18 March 2002, Clinton Administration Policy on Reforming Multilateral Peace Operations (PDD 25). Released on the WWW by the Bureau of International Organizational Affairs, U.S. Department of State, February 22, 1996; available from http://www.mikenew.com/ pdd 25.html

64. For additional views, see Walter E. Kretchik, Robert F. Baumann, and John T. Fishel, Invasion, Intervention, "Intervasion": A Concise History of the U.S. Army in Operation Uphold Democracy (Fort Leavenworth, KS: U.S. Army Command and General Staff College Press, 1998), and Karin von Hippel, Democracy by Force: US Military Intervention in the Post-Cold War World (Cambridge: Cambridge University Press, 2000). 